produced his definitive study $A$ World of Nations: Problems of Political Modernization (Brookings, 1967). Among his other numerous books are: Philosophers and Kings: Studies in Leadership (Braziller, 1971), Middle Eastern Political Systems (Prentice Hall 1971), OPEC: Success and Prospects (with John Mugno, Council on Foreign Relations, 1976), Oil and Turmoil: America Faces OPEC and the Middle East (Norton, 1982), Turkey: America's Forgotten Ally (Council on Foreign Relations, 1987) and Comparative Political Dynamics: Global Research Perspectives (ed. with K.P. Erickson, Harper Collins, 1991). Dan Rustow was most proud of his abridged translation of his father's Freedom and Domination: $A$ Historical Critique of Civilization (Princeton University Press, 1986).

Rustow authored scores of articles in scholarly journals. He contributed important articles to major reference works such as the Cambridge History of Islam, The Encyclopedia of Democracy, The Encyclopedia of Islam, The International Encyclopedia of the Social Sciences, and the Oxford Encyclopedia of the Modern Islamic World.

At his death Rustow was writing a comprehensive work on transitions to democracy.

Benjamin Rivlin

City University of New York

\section{William B. Rogers}

For the political science department of the State University of New York, College at Cortland, I am saddened to report the death, on January 23, 1996, of William B. Rogers, Distinguished Service Professor, Professor of Political Science, and former Chair of the SUNY Faculty Senate. Rogers, 68, died from congestive heart failure, the result of pulmonary disease and diabetes. He had been ill for some time and had borne his illness with his customary sardonic humor and stoic courage.

At the time of his death he lived in Burke, Virginia, where he moved in 1993. He retired in 1991, having been a member of the SUNYCortland faculty for thirty-three years. He received his B.A. degree from St. Lawrence University, and his M.A. from Colgate. He did grad- uate work at Syracuse University. At Cortland, he served on several occasions as department chair, Acting Dean of Arts and Sciences, and Chair of the Faculty Senate, among other responsibilities too numerous to note here. He was a retired Lieutenant-Commander in the Naval Reserve.

Bill Rogers taught thousands of students in his time at Cortland and hundreds of students received their first introduction to the law, to state and local government and to the New York Times Clipping Thesis (which he developed for the Times and which tens of thousands of students throughout the United States were also subjected to), and to a unique form of humor and old world professorial manner. Even in his last years, when his customary energy had flagged due to illness, he retained his commitment to his students and the College.

When Bill Rogers arrived at SUNY-Cortland, the College and the University were just beginning the transformation to a university composed of solid colleges of arts and sciences. For Rogers, teaching constitutional law and pre-law advising was a calling as well as a responsibility. Many of our students were the first in their families to attend college, the first to aspire to professional education, the first to display the success that we routinely call "the American dream." He created among them a will and desire to enter the legal profession; he mentored students as they took their first steps toward thinking about law; he carefully sought to match students with schools appropriate for their skills, talents, interests, and financial standing. He led them through the LSAT terrors, kept on them about their applications, intervened with law schools, followed up on their progress in law school, kept himself informed on the ups and downs of the profession, followed the legal careers of those he started on the path.

We were all rewarded, and none more than Bill Rogers himself, to see over the years our young nervous freshmen turn up as successful lawyers, DA's, judges, legislative staffers, and the like. As SUNY itself provided access to a generation of new college-going young people in New York, so also did Bill Rogers provide access for our students into the legal profession. He helped them and their families realize aspirations that would have been unthinkable only a generation earlier.

A colleague of the old school who never used a typewriter or computer and whose office overflowed with law books, clippings, Supreme Court slip opinions, student papers, sly jokes, puns and memos, and political and naval knick-knacks, he was a builder, colleague, teacher, and friend.

Henry Steck SUNY-Cortland

\section{Evelyn Paniagua Stevens}

Evelyn Paniagua Stevens, a political scientist and 10th President of the Latin American Studies Association (1976-77), who was born in Chicago in 1919, died on March 19, 1996, in Alameda, California.

Evelyn Stevens personified the change in the role of women in academe. During the 1940s and '50s, as a married woman without a college degree, she worked as a journalist and government employee, with the Army Corps of Engineers, the San Juan Star, the Office of the Governor of Puerto Rico, the Economic Development Administration, the Tenth Naval District Headquarters, and the National Labor Relations Board.

Evelyn had studied at Northwestern University and the University of Puerto Rico. After her two children were grown and she was divorced from her husband, Dr. Manuel Paniagua of San Juan, she resumed her college education, taking her A.B. degree at the age of 43 , her A.M., and then her Ph.D. at 49, all at the University of California at Berkeley. Phi Beta Kappa at Berkeley, she was a Fulbright Scholar in Mexico in 1965 , and then married her second husband, George Sayers, a professor of Physiology in the Medical School of Case Western Reserve University. She held teaching positions at the University of Akron and at Loyola University of Chicago and then served as Research Associate in the Latin American Studies Center of the University of California at Berkeley, where she continued her 
research and writing until her retirement.

Feisty and often irreverent, Evelyn Stevens was a sensitive and prescient observer of Latin American political culture. She was also the first woman president of the Latin American Studies Association (LASA), a post to which she brought both considerable skills developed before she entered academic life, and her vision that all publics-north and southshould be included in the work of the Association.

She was among the first to write on women's issues and concerns and was a leader of various groups of women Latin Americanists. A fighter to the last, Evelyn was determined to broaden LASA's base of support, include previously excluded groups, institutionalize and extend LASA's area of influence and expertise, and assure its growth and longevity. This she was able to do.

Jane S. Jaquette, Occidental College Felicity Trueblood, University of Florida Richard G. Stevens, Institute of World Politics

\section{Marvin Zetterbaum}

Marvin Zetterbaum, Emeritus Professor of Political Science at the University of California, Davis, died of pancreatic cancer on May 5, 1996. Although the course of the disease was swift, Zetterbaum had time to set his house in order and died at home, aware to the end, surrounded by his family, his friends, and his former students. It was typical of him that as his illness ran its course, he chose to avoid debilitating treatment and hospitalization in preference for consciousness, contact with others, and the opportunity for reflection. These were the themes of Marvin's life and they characterized him to the last.

Born in New York City in 1924, Zetterbaum attended the city's public schools and eventually entered City College. It will, no doubt, surprise many to learn that he started his college career as a Business Administration major. The Second World War interrupted his education, however, and from 1943-46 he served in the Air Force in the South Pacific. Like so many of his genera- tion, the wartime experience had a profound effect upon him. When he resumed civilian life, he did an educational about face and took on the great books, beginning school anew as a freshman at St. John's College, Annapolis. After St. John's, he went on to graduate school at the University of Chicago, where he joined the circle of extraordinary political philosophers and teachers who in the decade after the war studied with Leo Strauss. He received his Ph.D. from Chicago in 1960 . While pursuing his graduate studies he worked in various capacities, including director, in Chicago's Basic Liberal Arts Program. In 1961 he joined the faculty at Davis, where he remained, except for the occasional stint as a visiting professor, for the rest of his career. He retired from UCD in 1991 , but he continued teaching at the school on a recall basis until just before he fell ill. He is survived by his wife, Denise Zetterbaum; three children Andee, Jocelyn and Jordan Zetterbaum; and a sister, Estelle Weissman.

Marvin Zetterbaum was one of those increasingly rare cases where the line between scholarship and teaching is hard to detect. What Marvin taught, he wrote about, and what he wrote about was at the core of what he taught. This was always the case for him, but it became more emphatic as he matured. At Chicago, he did his dissertation work, apparently after some prodding by Allan Bloom, on the political philosophy of Alexis deTocqueville. This eventually became Tocqueville and the Problem of Democracy (Stanford, 1967). The themes raised there shaped Zetterbaum's subsequent research, and, I think, some unconventional career choices.

In studying Tocqueville, the analyst of the democratic psyche, Zetterbaum confronted, for the first time formally, the question of the intersection of politics and human nature. Reading Tocqueville carefully, Zetterbaum discovered a pessimist whose recognition that "nature dissociates men, at least in their civil capacities," leads him to defy and obscure nature in order that his students "turn their gaze outward," that is, away from themselves and towards others. Although Zetterbaum was sympathetic to Tocqueville's intention in the latter respect, he resisted Tocqueville's judgments on human nature and democratic men, and Tocqueville's purposeful obscurantism. Instead of going along, as so many of his colleagues, on the blind march of inevitability, Zetterbaum reopened the debate Tocqueville closed by recasting the quarrel between ancients and moderns in terms of modern notions like self, human need, and consciousness.

As Zetterbaum saw it, these were not merely academic issues. Their implications were, and are, enormous. Taking on the question of whether we are possessed of a permanent nature or are in some sense self-makers, for example, he observed that "we cannot abandon the search for human nature as we abandoned the concept of the 'state of nature' ... (for) this seeking for understanding of ourselves is constitutive of our being." For Zetterbaum, to be human, meant keeping open the door Tocqueville tries to close. To forsake the notion of human nature in favor of a contemporary understanding of man as self-maker was, therefore, unacceptable. If we are committed to the truth, as he put it, we are not free to decide that man is a self-maker since that would be "merely another self-interpretation." Zetterbaum, in this sense, shrunk from taking the side of Nietzsche, as he had earlier shrunk from taking that of Tocqueville. On the other hand, he was no doctrinaire on the question of the relative merits of the ancients and moderns. Indeed, in a remarkable paper he delivered at the APSA meeting in 1983 , he declared himself to be "a not-so-well-hidden closet modern" and applauded some of modern psychology and psychotherapy for rescuing the self from disrepair and from a sterile identification with will. In the end, then, Zetterbaum overcame Tocqueville. In so doing, he also opened himself to a new career that demonstrated the union in him of the theoretical and practical. For twenty odd years, until his death, he was a certified psychotherapist in private practice.

A word needs also to be said about Zetterbaum as a teacher. Consistent with his concern for what 